\title{
PENGARUH SALES PROMOTION DAN STORE ATMOSPHERE TERHADAP IMPULSE BUYING DENGAN POSITIVE EMOTION SEBAGAI VARIABEL INTERVENING PADA PLANET SPORTS TUNJUNGAN PLAZA SURABAYA
}

\author{
Oky Gunawan Kwan \\ Pemerhati Fashion Marketing di Surabaya \\ E-mail: oky_gunawan_94@yahoo.com
}

\begin{abstract}
Abstrak: Penelitian ini bertujuan untuk menganalisa pengaruh dari Sales Promotion dan Store Atmosphere terhadap Impulse Buying dengan Postivie Emotion sebagai variabel intervening pada Planet Sports Tunjungan Plaza Surabaya. Penelitian ini akan dilaksanakan dengan menyebarkan kuesioner kepada 100 responden konsumen Planet Sports. Teknik analisa yang digunakan adalah teknik analisis kuantitatif dengan metode path analysis. Hasil Penelitian ini menunjukkan bahwa sales promotion berpengaruh secara positif dan signifikan terhadap impulse buying, store atmosphere berpengaruh secara positif dan signifikan terhadap impulse buying, positive emotion berpengaruh secara positif dan signifikan terhadap impulse buying.
\end{abstract}

Kata kunci: Sales Promotion, Store Atmosphere, Impulse Buying, Positive Emotion.

\begin{abstract}
This research aims to analyze the impact of Sales Promotion and Store Atmosphere towards Impulse Buying through consideration of Positive Emotion at Planet Sports Tunjungan Plaza Surabaya. This research will be conducted by distributing questionnaires to 100 respondents which are consumer of Planet Sports. Quantitative analysis with path analysis analysis model method were used for the technical analysis.The results of this study indicate that the sales promotion influence positively and significantly related to impulse buying, store atmosphere affect positively and significantly related to impulse buying, positive emotion in a positive and significant impact on impulse buying.
\end{abstract}

Keywords: Sales Promotion, Store Atmosphere, Impulse Buying, Positive Emotion

\section{PENDAHULUAN}

Saat ini bisnis retail Indonesia sedang mengalami kemajuan yang sangat pesat. Fenomena bisnis ritel biasanya sering kali dilihat sebagai gambaran perekonomian suatu negara. Perkembangan penyewaan tempat olahraga semakin meningkat seperti lapangan futsal, basket, dan bulu tangkis di Surabaya. Karena itu peluang dalam bisnis retail specialty store sport equipment sangat menjanjikan, diketahui bahwa inovasi-inovasi produk dalam dunia olahraga sangat cepat sekali terutama dalam segi model produk itu sendiri seperti contohnya sepatu dan jersey. Planet Sports merupakan salah satu retail yang menjual produk olahraga terlengkap dengan konsep Specialty Store.

Promosi adalah suatu komunikasi informasi penjual dan pembeli yang bertujuan untuk merubah sikap dan tingkah laku pembeli, yang sebelumnya tidak paham menjadi paham sehingga menjadi pembeli dan mengingat produk tersebut (Denny Kurniawan, 2013).

Store Atmosphere adalah keadaan toko yang didesain semenarik mungkin untuk mempengaruhi konsumen dalam melakukan pembelian. Store Atmosphere adalah langkah untuk memanipulasi desain bangunan, ruangan interior, tata ruang lorong-lorong, tekstur karpet dan dinding, bau, warna, bentuk dan suara yang dialami para pelanggan untuk mencapai pengaruh tertentu (Ratnasari, 2015).

Positive Emotions adalah faktor yang dapat mempengaruhi terjadinya Impulse Buying ketika sedang berbelanja, dimana konsumen sedang mengalami perasaan senang atau gembira. Keadaan emosional yang positif akan membuat dua perasaan yang dominan yaitu perasaan senang dan membangkitkan keinginan, baik yang muncul dari psikologikal set ataupun keinginan yang bersifat mendadak impulse (I Made Willy Setiadi \& I Gede Ketut Warmika, 2015).

Impulse Buying sebagai kecenderungan konsumen untuk membeli secara spontan, reflek, tiba-tiba, dan otomatis. Dari penjelasan tersebut menunjukan bahwa Impulse Buying dapat terjadi kapan dan dimanapun (Pattipeilohy, Rofiaty, \& Idrus, 2013).

Berdasarkan latar belakang yang telah dikemukakan, maka permasalahan yang ditimbulkan adalah:

1. Apakah Sales Promotion berpengaruh terhadap Positive Emotion konsumen Planet Sports Tunjungan Plaza Surabaya?

2. Apakah Store Atmosphere berpengaruh terhadap Positive Emotion konsumen Planet Sports Tunjungan Plaza Surabaya? 
3. Apakah Positive Emotion berpengaruh terhadap Impulse Buying konsumen Planet Sports Tunjungan Plaza Surabaya?

4. Apakah Sales Promotion berpengaruh terhadap Impulse Buying konsumen Planet Sports Tunjungan Plaza Surabaya?

5. Apakah Store Atmosphere berpengaruh terhadap Impulse Buying konsumen Planet Sports Tunjungan Plaza Surabaya?

\section{TINJAUAN PUSTAKA}

\section{Sales Promotion}

Sales promotion adalah program promosi peritel dalam rangka mendorong terjadinya penjualan atau untuk meningkatkan penjualan atau dalam rangka mempertahankan minat pelanggan untuk tetap berbelanja padanya (Hendri Ma'ruf, 2005). Sales Promotion, terdiri dari dua dimensi yang berkaitan dengan uang (monetary) dan tidak berkaitan dengan uang (non-monetary):

1) Monetary

Monetary merupakan promosi penjualan yang berkaitan dengan uang. Promosi monetary berbentuk pemberian potongan harga secara intensif pada konsumen saat melakukan pembelian.

2) Non-Monetary

Non-monetary merupakan promosi penjualan yang tidak berkaitan dengan uang, merupakan promosi penjualan yang tidak memberikan intensif secara langsung dan lebih berdasar pada hubungan dengan konsumen.

\section{Store Atmosphere}

Store Atmosphere adalah desain lingkungan melalui komunikasi visual, pencahayaan, warna, musik, dan wangi-wangian untuk merancang respon emosional dan persepsi pelanggan dan untuk mempengaruhi pelanggan dalam membeli barang" (Nofiawaty, 2014).

Element-element dari store atmosphere dibagi ke dalam 4 dimensi (Nofiawaty, 2014), yaitu:

1) Exterior

Bagian depan toko adalah bagian yang termuka. Maka ia hendaknya memberikan kesan yang menarik. Dengan mencerminkan kemantapan dan kekokohan, maka bagian depan dan bagian luar ini dapat menciptakan kepercayaan dan goodwill.

2) General Interior

Berbagai motif konsumen memasuki toko, hendaknya memperoleh kesan yang menyenangkan. Kesan ini dapat diciptakan misalnya dengan warna dinding toko yang menarik, musik yang diperdengarkan, serta aroma/bau dan udara di dalam toko.

3) Store Layout

Merupakan rencana untuk menentukan lokasi tertentu dan pengaturan dari Jalan/gang di dalam toko yang cukup lebar dan memudahkan orang untuk berlalu-lalang, serta fasilitas toko seperti kelengkapan ruang ganti yang baik dan nyaman.

4) Interior Display

Sangat menentukan bagi suasana toko karena memberikan informasi kepada konsumen. Tujuan utamanya adalah untuk meningkatkan penjualan dan laba bagi toko. Yang termasuk interior display ialah: poster, tanda petunjuk lokasi, display barang-barang pada hari-hari khusus seperti lebaran dan tahun baru.

\section{Positive Emotion}

Pada dasarnya emosi yang terdapat di dalam diri manusia terdiri dari dua bagian yaitu Positive Emotion dan Negative Emotion. Munculnya kemungkinan dua bagian emosi tersebut di dalam diri konsumen tergantung stimulus yang diberikan oleh toko sehingga dapat mempengaruhi keadaan emosi dari konsumen. Berikut adalah definisi dan penjelasan mengenai emosi positif dan emosi negatif (Andriyanto, 2016)

Respon afektif lingkungan atas perilaku pembelian dapat diuraikan oleh 3 variabel (Darma \& Japarianto, 2014) yaitu:

1) Pleasure

Mengacu pada tingkat di mana individu merasakan baik, penuh kegembiraan, bahagia yang berkaitan dengan situasi tersebut. Pleasure diukur dengan penilaian reaksi lisan ke lingkungan (bahagia sebagai lawan sedih, menyenangkan sebagai lawan tidak menyenangkan, puas sebagai lawan tidak puas, penuh harapan sebagai lawan berputus asa, dan santai sebagai lawan bosan). Konseptualisasi terhadap pleasure dikenal dengan pengertian lebih suka, kegemaran, perbuatan positif.

2) Arousal

Mengacu pada tingkat di mana seseorang merasakan siaga, digairahkan, atau situasi aktif. Arousal secara lisan dianggap sebagai laporan responden, seperti pada saat dirangsang, ditentang atau diperlonggar. Beberapa ukuran non verbal telah diidentifikasi dapat dihubungkan dan sesungguhnya membatasi sebuah ukuran dari arousal dalam situasi sosial.

3) Dominance

Variabel ini ditandai dengan laporan responden yang merasa dikendalikan sebagai lawan mengen- 
dalikan, mempengaruhi sebagai lawan dipengaruhi, terkendali sebagai lawan diawasi, penting sebagai lawan dikagumi, dominan sebagai lawan bersikap tunduk dan otonomi sebagai lawan dipandu.

Konsumen dengan Positive Emotions menunjukkan dorongan yang lebih besar dalam melakukan pembelian karena memiliki perasaan yamg tidak dibatasi oleh keadaan lingkungan sekitarnya, memiliki keinginan untuk menghargai diri mereka sendiri, dan tingkat energi yang lebih tinggi (Andriyanto, 2016).

\section{Impulse Buying}

Impulse Buying didefinisikan sebagai "tindakan membeli yang sebelumnya tidak diakui secara sadar sebagai hasil dari suatu pertimbangan atau niat membeli yang terbentuk sebelum memasuki toko" (Denny Kurniawan, 2013).

Dari hasil penelitian yang dilakukan sebelumnya, pembelian yang tidak terencana (impulse buying) dapat diklasifasikan dalam empat tipe: planned impulse buying, reminded impulse buying, suggestion impulse buying, dan pure impulse buying (Japarianto, 2009).

1) Pure Impulse Buying

Merupakan pembelian secara impulse yang dilakukan karena adanya luapan emosi dari konsumen sehinga melakukan pembelian terhadap produk di luar kebiasaan pembeliannya.

2) Reminder Impulse Buying

Merupakan pembelian yang terjadi karena konsumen tiba-tiba teringat untuk melakukan pembelian produk tersebut. Dengan demikian konsumen telah pernah melaku-kan pembelian sebelumnya atau telah pernah melihat produk tersebut dalam iklan.

3) Suggestion Impulse Buying

Merupakan pembelian yang terjadi pada saat konsumen melihat produk, melihat tata cara pemakaian atau kegunaannya, dan memutuskan untuk melakukan pembelian.

4) Planned Impulse Buying

Merupakan pembelian yang terjadi ketika konsumen membeli produk berdasarkan harga spesial dan produk-produk tertentu. Dengan demikian planned impulse buying merupakan pembelian yang dilakukan tanpa direncanakan dan tidak tengah memerlukannya dengan segera.

\section{Kerangka Konseptual}

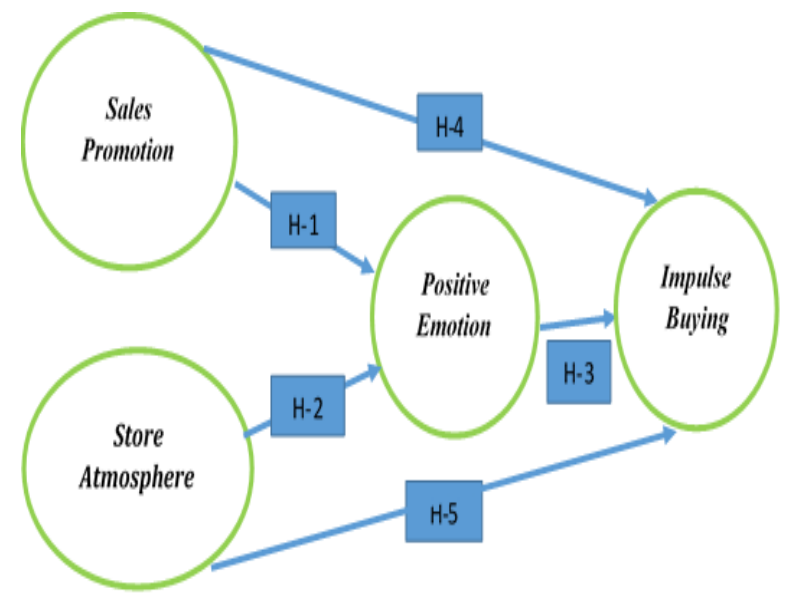

Gambar 1. Kerangka konseptual

\section{Hipotesis}

Adapun hipotesis yang diajukan pada penelitian ini adalah:

H1: Sales Promotion berpengaruh positif terhadap Positive Emotion

H2: Store Atmosphere berpengaruh positif terhadap Positive Emotion

H3: Positive Emotion berpengaruh positif terhadap Positive Emotion

H4: Sales Promotion berpengaruh positif terhadap Impulse Buying

H5: Store Atmosphere berpengaruh positif terhadap Impulse Buying

\section{METODE PENELITIAN}

\section{Populasi dan Sampel}

Populasi adalah wilayah generalisasi yang terdiri atas obyek atau subyek yang memiliki karakteristik tertentu yang kemudian ditetapkan oleh peneliti untuk dipelajari dan ditarik kesimpulannya (Sugiyono, 2011). Populasi yang dipilih dalam penelitian ini adalah masyarakat kota Surabaya yang pernah berbelanja produk yang dijual oleh Planet Sports Tunjungan Plaza Surabaya.

Teknik pengambilan sampel dalam penelitian ini adalah non probability sampling, yaitu teknik pengambilan sampel yang tidak memberi peluang atau kesempatan yang sama bagi setiap unsur atau anggota populasi untuk dipilih menjadi sampel (Sugiyono, 2011). Teknik ini untuk mempermudah pengambilan sampel yang memiliki jumlah populasi tidak terdata. 
Pelanggan yang menjadi sampel sebagai responden dalam penelitian ini adalah pelanggan yang pernah membeli produk dari Planet Sports setidaknya satu kali. Selain itu, jangka waktu pembelian produk dari Planet Sports setidaknya 2x dalam 3 bulan terakhir pada saat pengisian kuesioner (April 2016Juni 2016).

Penelitian ini menggunakan sampel sebanyak 100 responden, dengan berdasarkan pada pertimbangan tingkat keyakinan 0,95 dengan $\alpha 0,05$ dan kesalahan yang mungkin terjadi tidak lebih dari $10 \%$.

\section{Definisi Operasional Variabel}

Definisi operasional variabel yang akan digunakan dalam penelitian ini terdiri dari 4 variabel, yaitu:

- Variabel eksogen/independen, yaitu Sales Promotion (X 1) dengan dimensi:

$\mathrm{X} 11=$ Monetary

Mernupakan promosi penjualan yang berkaitan dengan uang. Jenis-jenis promosi penjualan ini seperti diskon, cash back, dan paket harga.

- Variabel eksogen/independen, yaitu Store Atmosphere (X 2) dengan dimensi:

$\mathrm{X} 21=$ Exterior

Di definisikan sebagai bagian yang termuka. Maka ia hendaknya memberikan kesan yang menarik. Dengan mencerminkan kemantapan dan kekokohan, maka bagian depan dan bagian luar ini dapat menciptakan kepercayaan dan goodwill. X22 = General Interior

Di definisikan sebagai kesan yang menarik didalam toko, hal ini dapat diciptakan misalnya dengan warna dinding toko yang menarik, musik yang diperdengarkan, serta aroma/bau dan udara di dalama toko.

X23 = Store Layout

Di definisikan sebagai rencana untuk menentukan lokasi tertentu dan pengaturan dari jalan/gang di dalam toko yang cukup lebar dan memudahkan orang untuk berlalu-lalang, serta fasilitas lainnya yang mendukung keberlangsungan toko.

X24 = Interior Display

Di definisikan sebagai property dari toko yang dapat menunjang penyampaian informasi tentang suatu produk baru atau diskon terhadap konsumen.

- Variabel Intervening yaitu, Positive Emotion (Y) dengan dimensi, sebagai berikut:

$\mathrm{Y} 1=$ Pleasure

Adalah tingkatan dimana individu merasakan halhal baik dalam dirinya.

Y2 = Arousal

Adalah gairah atau reaksi yang timbul dalam diri individu akibat adanya rangsangan.
Variabel Endogen (Z) yaitu impulse buying

behavior, dengan dimensi:

$\mathrm{Z} 1=$ Pure Impulse Buying

Adanya luapan emosi dari konsumen sehinga melakukan pembelian terhadap produk di luar kebiasaan pembeliannya.

\section{$\mathrm{Z} 2$ = Reminder Impulse Buying}

Terjadi karena konsumen tiba-tiba teringat untuk melakukan pembelian produk tersebut.

Z3 = Suggestion Impulse Buying

Terjadi pada saat konsumen melihat produk, melihat tata cara pemakaian atau kegunaannya, dan memutuskan untuk melakukan pembelian.

$\mathrm{Z4}=$ Planed Impulse Buying

Terjadi ketika konsumen membeli produk berdasarkan harga spesial dan produk-produk tertentu.

\section{Teknik Analisis Data}

Pengujian hipotesis pada penelitian ini dilakukan dengan menggunakan teknik path analysis. Teknik path analysis di kembangkan oleh Sewal Wright pada tahun 1934. Pengujian statistik pada model path analysis dalam penelitian ini dilakukan dengan menggunakan metode partial least square regression. Pengolahan data menggunakan program smartPLS.

\section{HASIL PENELITIAN DAN PEMBAHASAN}

Evaluasi Path Coefficient dan Coefficient of Determination (R 2)

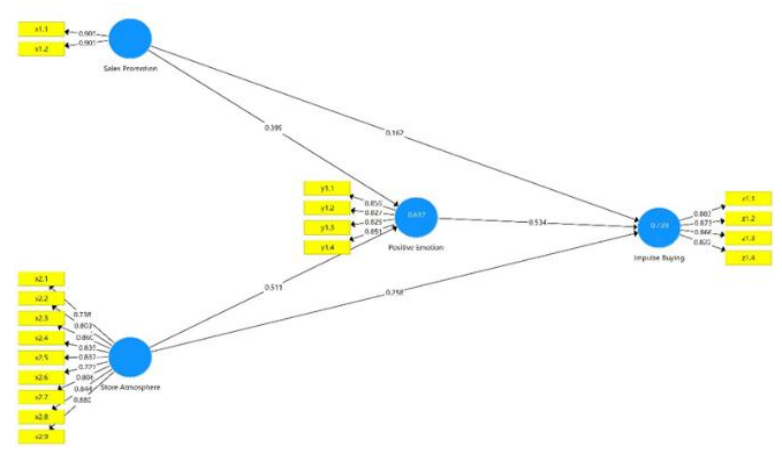

Gambar 2. Path Coefficient dan Coefficient of Determination

Pada analisa path coefficient ini telah dibuktikan bahwa positive emotion merupakan variabel intervening dimana memperkuat hubungan antara sales promotion dan store atmosphere.

Dari gambar diatas dapat dijelaskan bahwa nilai path coefficient terbesar ditunjukan dari pengaruh positive emotion terhadap impulse buying sebesar 0,534 . 
Selain itu, dapat dilihat pula bahwa keseluruhan variabel dalam model ini memiliki path coefficient dengan angka yang positif. Artinya, jika semakin besar nilai path coefficient pada satu variabel independen terhadap variabel dependen, maka semakin kuat juga pengaruh antara variabel independen terhadap variabel dependen tersebut.

Sementara itu, nilai coefficient of determination $\left(\mathrm{R}^{2}\right)$ yang pada gambar ditunjukan pada angka di dalam lingkaran positive emotion terhadap impulse buying, membuktikan bahwa variabel positive emotion dipengaruhi oleh variabel sales promotion, positive emotion dengan nilai varian sebesar 0,637. Lalu variabel impulse buying dipengaruhi sales promotion, store atmosphere, dan positive emotion dengan nilai varian sebesar 0,739 .

\section{T-statistics}

Tabel 5. T-statistics

\begin{tabular}{|c|c|c|c|c|}
\hline & $\begin{array}{c}\text { Original } \\
\text { Sample } \\
\text { (O) }\end{array}$ & $\begin{array}{l}\text { Sample } \\
\text { Mean } \\
\text { (M) }\end{array}$ & $\begin{array}{c}\text { Standard } \\
\text { Deviasi } \\
\text { (STDEV) }\end{array}$ & $\begin{array}{c}\text { T Statistics } \\
(|\mathrm{O} / \mathrm{STDEV}|)\end{array}$ \\
\hline $\begin{array}{l}\text { Sales } \\
\text { Promotion } \\
\rightarrow \text { Positive } \\
\text { emotion }\end{array}$ & 0,399 & 0,384 & 0,109 & 3,661 \\
\hline $\begin{array}{l}\text { Store } \\
\text { Atmosphere } \\
\rightarrow \text { Positive } \\
\text { emotion }\end{array}$ & 0,511 & 0,526 & 0,102 & 4,993 \\
\hline $\begin{array}{l}\text { Positive } \\
\text { emotion } \\
\rightarrow \text { Impulse } \\
\text { Buying }\end{array}$ & 0,534 & 0,520 & 0,125 & 4,280 \\
\hline $\begin{array}{l}\text { Sales } \\
\text { Promotion } \\
\rightarrow \text { Impulse } \\
\text { Buying }\end{array}$ & 0,162 & 0,149 & 0,078 & 2,073 \\
\hline $\begin{array}{l}\text { Store } \\
\text { Atmosphere } \\
\rightarrow \text { Impulse } \\
\text { Buying }\end{array}$ & 0,258 & 0,281 & 0,122 & 2,120 \\
\hline
\end{tabular}

T-statistics pada pengaruh sales promotion terhadap Positive emotion menunjukkan 3,661203, artinya sales promotion berpengaruh signifikan terhadap positive emotion. T-statistics pada pengaruh store atmosphere terhadap positive emotion menunjukkan 4,993149, artinya store atmosphere berpengaruh signifikan terhadap positive emotion. T-statistics pada pengaruh positive emotion terhadap impulse buying menunjukkan 4,279842, artinya positive emotion berpengaruh signifikan terhadap impulse buying. T-statistics pada pengaruh sales promotion terhadap impulse buying menunjukkan angka
2,072950 , artinya sales promotion berpengaruh signifikan terhadap impulse buying. T-statistics pada pengaruh store atmosphere terhadap impulse buying menunjukkan 2,119948, artinya store atmosphere berpengaruh signifikan terhadap impulse buying.

\section{Uji Hipotesis}

Tabel 6. Kesimpulan Hipotesis

\begin{tabular}{|c|c|c|}
\hline Hipotesis & Keterangan & T-statistics \\
\hline $\mathrm{H}_{1}$ & $\begin{array}{l}\text { Terdapat pengaruh signifikan } \\
\text { dari sales promotion terhadap } \\
\text { positive emotion }\end{array}$ & 3,661203 \\
\hline $\mathrm{H}_{2}$ & $\begin{array}{l}\text { Terdapat pengaruh signifikan } \\
\text { dari store atmosphere terhadap } \\
\text { positive emotion }\end{array}$ & 4,993149 \\
\hline $\mathrm{H}_{3}$ & $\begin{array}{l}\text { Terdapat pengaruh signifikan } \\
\text { dari positive emotion terhadap } \\
\text { impulse buying }\end{array}$ & 4,279842 \\
\hline $\mathrm{H}_{4}$ & $\begin{array}{l}\text { Terdapat pengaruh signifikan } \\
\text { dari sales promotion terhadap } \\
\text { impulse buying }\end{array}$ & 2,072950 \\
\hline $\mathrm{H}_{5}$ & $\begin{array}{l}\text { Terdapat pengaruh signifikan } \\
\text { dari store atmosphere terhadap } \\
\text { impulse buying }\end{array}$ & 2,119948 \\
\hline
\end{tabular}

Pengaruh antar variabel dikatakan bersifat signifikan apabila nilai $T$-statistics lebih besar dari angka 1,96. Sehingga diketahui bahwa berdasarkan Tabel 6, terdapat pengaruh signifikan antara variabel sales promotion terhadap positive emotion, terdapat pengaruh signifikan antara store atmosphere terhadap positive emotion, terdapat pengaruh signifikan antara positive emotion terhadap impulse buying, terdapat pengaruh yang signifikan antara sales promotion terhadap impulse buying, dan terdapat pengaruh yang signifikan antara store atmosphere terhadap impulse buying.

\section{Pembahasan}

\section{Sales Promotion terhadap Positive Emotion}

Pada hasil penelitian ini dapat diketahui bahwa sales promotion dari Planet Sports memiliki pengaruh yang signifikan terhadap positive emotion konsumen dengan nilai uji T-statistics > 1.96 yaitu 3,661203.

Hasil penelitian ini juga menunjukkan bahwa sales promotion berpengaruh signifikan terhadap positive emotion. Hal ini sesuai dengan pendapat yang dikemukakan oleh (Denny Kurniawan, 2013) bahwa sales promotion yang baik akan menciptakan persepsi yang menguntungkan bagi konsumen ketika membeli produk tersebut dan memancing ketertarikan konsumen untuk membeli produk di Planet Sports yang 
pada akhirnya mempengaruhi perilaku pembelian sehingga sales promotion dapat meningkatkan positive emotion dari konsumen. Seperti contoh ketika konsumen mengunjungi Planet Sports kemudian melihat barang yang sedang di diskon atau promo hal tersebut membuat konsumen tertarik untuk membeli karena dirasa menguntungkan dan konsumen menjadi senang dan puas dalam berbelanja sehingga meningkatkan positive emotion mereka ketika berada di Planet Sports.

\section{Store Atmosphere terhadap Positive Emotion}

Hasil penelitian ini juga menunjukkan bahwa store atmosphere berpengaruh sginfikan terhadap positive emotion. Hal ini sesuai dengan pendapat yang dikemukakan oleh (Restuti, 2014) dimana suasana toko yang secara tidak sadar dirasakan oleh pelanggan sangat mempengaruhi emosi mereka dalam berbelanja sehingga pelanggan menjadi nyaman dan dapat berlama-lama di dalam toko. Ketika pelanggan merasakan suasana yang baik, maka secara tidak langsung emosi positif yang dimiliki pengunjung juga ikut meningkat. Hal ini berarti konsumen tersebut merasa nyaman dengan suasana yang ada di Planet Sports. Contoh dari dampak store atmosphere Planet Sports yaitu pelanggan merasa senang berbelanja dan melihat produk-produk yang ada di Planet Sports karena memiliki tempat yang luas dan penataan produk yang rapi sehingga pelanggan betah untuk berlama-lama di Planet Sports.

Pada hasil penelitian ini diketahu bahwa pengaruh secara signifikan tersebut merupakan hasil uji Tstatistics dengan nilai 4,993149, yaitu diatas 1,96. Sehingga diketahui bahwa store atmosphere yang dirasakan pelanggan Planet Sports mempengaruhi positive emotion yang didapat.

\section{Positive Emotion terhadap Impulse Buying}

Hasil penelitian ini juga dapat dibuktikan bahwa positive emotion memiliki pengaruh signifikan terhadap impulse buying. Pada hubungan ini, positive emotion muncul disebabkan hasil dari rangsangan dari internal dan eksternal individu yang pada akhirnya mempengaruhi konsumen tersebut untuk melakukan pembelian tidak terrencana tersebut. Hal tersebut menyatakan bahwa hasil penelitian ini sejalan dengan pendapat yang dikemukakan oleh (Hetharie, 2012) bahwa konsumen yang memiliki emosi yang baik akan tinggal lebih lama di dalam toko maka akan lebih tertarik untuk melakukan pembelian di toko tersebut sehingga terciptalah impulse buying.

Pada hasil penelitian ini diketahui bahwa pengaruh secara signifikan tersebut merupakan hasil uji T-statistics dengan nilai 4,279842, yaitu diatas 1,96. Sehingga dapat disimpulkan bahwa positive emotion mempengaruhi impulse buying dibenak pelanggan Planet Sports.

Hal ini menunjukkan bahwa positive emotion memiliki dampak yang cukup besar dalam terjadinya impulse buying. Contohnya adalah seperti ketika pengunjung masuk ke Planet Sports kemudian mereka melihat adanya diskon atau promo yang ditawarkan dan kemudian didukung oleh penciptaan suasana dari store sehingga mengakibatkan pengunjung merasa senang dan ingin berbelanja yang diluar daftar keperluan mereka.

\section{Sales Promotion terhadap Impulse Buying}

Pada hasil penelitian ini dapat diketahui bahwa sales promotion mempunyai pengaruh yang positif dan signifikan terhadap impulse buying. Dengan nilai uji T-statistics $>1,96$ yaitu sebesar 2,072950.

Hasil penelitian yang dilakukan menyatakan bahwa sales promotion memiliki hubungan yang signifikan dan positif terhadap impulse buying. Hal ini sesuai dengan yang dikemukakan oleh (Leba, 2015) bahwa Toko yang memiliki program sales promotion yang baik akan lebih mudah menciptakan terjadinya impulse buying terhadap konsumen, dibandingkan dengan toko yang tidak memiliki program sales promotion yang efektif kepada konsumen. Sama halnya dengan Planet Sports yang melakukan program sales promotion dengan baik yaitu memberikan diskon dan cashback pada produk yang mereka jual sehingga pengunjung dapat tertarik dan berminat membeli meskipun tidak merencanakan pembelian tersebut karena konsumen sangat senang membeli barang yang sedang di diskon.

\section{Store Atmosphere terhadap Impulse Buying}

Dari hasil analisa penelitian ini juga dapat dibuktikan bahwa store atmosphere memiliki pengaruh yang signifikan terhadap impulse buying. Pada hubungan ini, impulse buying muncul dapat disebabkan dari hasil rangsangan suasana toko yang mendukung sehingga terjadinya keputusan pembelian yang tidak direncanakan tersebut. Hal tersebut sejalan dengan pendapat yang dikemukakan oleh (Yistiani, 2012) yang menyatakan penciptaan suasana pada toko yang baik akan meningkatkan pembelian impulsif.

Pada hasil penelitian ini diketahui bahwa pengaruh secara siginifikan tersebut merupakan hasil uji Tstatistics dengan nilai 2,119948, yaitu diatas 1,96. Sehingga dapat disimpulkan bahwa Store Atmosphere 
mempengaruhi impulse buying dibenak konsumen Planet Sports.

Terdapat pengaruh yang terjadi namun store atmosphere memiliki peranan yang tidak terlalu besar dalam terbentuknya pembelian tidak terrencana konsumen Planet Sports. Jadi untuk kasus Planet Sports, impulse buying terjadi bukan karena efek suasana yang mendukung.

\section{KESIMPULAN DAN SARAN}

\section{Kesimpulan}

Berdasarkan hasil penelitian mengenai analisa pengaruh sales promotion dan store atmosphere terhadap impulse buying dengan positive emotion sebagai variabel intervening di Planet Sports Tunjungan Plaza.

Dapat ditarik sebuah kesimpulan bahwa sales promotion dan store atmosphere merupakan variabel yang berpengaruh dalam menciptakan positive emotion dan impulse buying terhadap konsumen di Planet Sports. Dimana dalam penelitian ini membuktikan bahwa sebuah toko yang dapat menarik minat konsumen adalah toko yang memiliki sales promotion dan store atmosphere yang dilakukan dengan baik dan benar. Penelitian ini membahas dengan adanya variabel-variabel tersebut membuat penliaian bahwa Planet Sports berhasil dalam menjalankan program promosi dan desain toko yang dirancang oleh mereka.

\section{Saran}

Meningkatkan Sales Promotion dari Planet Sports karena Sales Promotion berpengaruh terhadap Positive Emotion dan Impulse Buying dari Planet Sports.

Implementasi yang bisa dilakukan oleh Planet Sports adalah untuk manajemen dari Planet Sports harus dapat mempertahankan serta meningkatkan kualitas dari program sales promotion secara intens, kemudian menambahkan jenis dari promosi tidak harus selalu diskon dan cashback.

Untuk peneliti selanjutnya, peneliti dapat lebih memperhatikan variabel store atmosphere. Variabel ini dapat didetailkan pada bagian dimensi eksterior bisa dijabarkan sesuai dengan pengertiannya. Dapat diberikan contoh indikator seperti akses pintu masuk Planet Sports yang besar memudahkan pengunjung untuk berlalu-lalang dan warna tampilan luar Planet Sports yang menunjukkan semangat untuk beraktivitas. Hal ini bisa menjelaskan lebih detail mengenai hubungan antara store atmosphere terhadap positive emotion.

\section{DAFTAR PUSTAKA}

Andriyanto, D. S. (2016). Pengaruh Fashion Involvement dan Positive Emotion Terhadap Impulse Buying (Survey pada Warga Kelurahan Tulusrejo Kecamatan Lowokwaru Kota Malang), 31(1), 42-49.

Darma, L. A., \& Japarianto, E. (2014). Analisa Pengaruh Hedonic Shopping Value Terhadap Impulse Buying Dengan Shopping Lifestyle dan Positive Emotion Sebagai Variabel Intervening pada Mall Ciputra, 8(2), 80-89. http://doi.org/ 10.9744/pemasaran.8.2.80-89

Denny Kurniawan, (2013). Pengaruh Promosi dan Store Atmosphere Terhadap Impulse Buying dengan Shopping Emotion Sebagai Variabel Intervening Studi Kasus di Matahari Department Store Cabang Supermall Surabaya, 1(2), 1-8.

Hendri Ma'ruf. (2005). Pemasaran Ritel. Jakarta: Gramedia Pustaka Utama.

Hetharie, J. A. (2012). Peran Emosi Positif sebagai Mediator Stimulus Lingkungan Toko dan Faktor Sosial terhadap Impulse Buying Tendency pada Matahari Departement Store Kota Ambon, 10.

I Made Willy Setiadi \& I Gede Ketut Warmika, (2015). Pengaruh Fashion Involvement Terhadap Impulse Buying Konsumen Fashion yang Dimediasi Positive Emotion di Kota Denpasar, 4(6), 1684-1700.

Japarianto, E. (2009). Pengaruh Shopping Life Style dan Fashion Involvement Terhadap Impulse Buying Behavior Masyarakat High Income Surabaya.

Leba, E. (2015). Pengaruh atmosfer gerai dan promosi terhadap pembelian impulsif yang dimediasi emosi positif, 4, 1-17.

Nofiawaty, B.Y. (2014). Pengaruh Store Atmosphere Terhadap Keputusan Pembelian Konsumen pada Outlet Nyenyes Palembang. Jurnal Manajemen dan Bisnis Sriwijaya, 12.

Pattipeilohy, V.R., Rofiaty, \& Idrus, M.S. (2013). The Influence of the availability of Money and Time, Fashion Involvement, Hedonic Consumption Tendency and Positive Emotions towards Impulse Buying Behavior in Ambon City (Study on Purchasing Products Fashion Apparel). International Journal of Business and Behavioral Sciences, 3(8), 36-49.

Ratnasari, V.A. (2015). Pengaruh Store Atmosphere Terhadap Hedonic Shopping Value dan Impulse Buying (Survei Pada Konsumen Hypermart Malang Town Square), 1(1).

Restuti, S. (2014). Pengaruh Sales Promotion dan Store Atmosphere Terhadap Shopping Emotion dan Impulse Buying pada Giant Pekanbaru, VI(3). 
JURNAL MANAJEMEN PEMASARAN, VOL. 10, NO. 1, April 2016: 27-34

Sugiyono. (2011). Metode Penelitian Kuantitatif, Kualitatif dan $R$ \& D. Bandung: Alfabeta.
Yistiani, N. N. M. (2012). Terhadap Nilai Hedonik dan Pembelian Impulsif Pelanggan Matahari Department Store Duta Plaza, 6(2), 139-149. 